\title{
LYMPHADENOPATHY IN TOXOPLASMOSIS
}

\author{
BY \\ J. K. A. BEVERLEY, J. P. CALEY, AND A. J. N. WARRACK \\ From the Department of Bacteriology, University of Sheffield, and the City General Hospital, Sheffield
}

(RECEIVED FOR PUBLICATION JULY 11, 1957)

The clinical signs of congenital toxoplasmosis are now well known, but those of post-natally acquired infections have received less attention.

Sabin (1941) recorded two cases which presented as meningoencephalitis, and Pinkerton and Henderson (1941) described two cases which resembled typhus.

In 1951 Siim reported seven cases which had generalized lymph node enlargement not unlike glandular fever. Since then many other cases of lymphadenopathy have been described (see Siim, 1956).

The latter type of illness appears to be much commoner than the others described. In most cases there have been abnormal cells of the lymphocyte-monocyte series in the peripheral blood and in none of them has the Paul-Bunnell test been positive. In only a few cases have lymph nodes been submitted to histological examination, and the purpose of this report is to describe a case in which the histological appearance resembled that described by Robb-Smith (1947) as lympho-histiocytic medullary reticulosis.

\section{Case Report}

Miss I. P., aged 26 years, attended the Medical OutPatient Department on August 13, 1956. She had been in good health until three days previously when she developed throbbing occipital headaches present on waking and continuous throughout the day. She also complained of a constant, dull low back pain radiating into the back of both thighs. Her symptoms were aggravated by change of posture and caused loss of sleep. Until two weeks before her illness she had been living in York where she was employed as a Government driver. Her work involved visits to outlying farms and she was in close and frequent contact with animals.

Examination revealed an intelligent and wellnourished woman. She was flushed but afebrile. The conjunctivae were of good colour and there was no skin rash. The fauces were clear and no palpable lymph nodes were detected. The heart and lungs were within normal limits at clinical examination. The liver and spleen were not palpable. In the central nervous system the optic fundi showed no abnormality and the cranial nerves were likewise normal. There was no neck rigidity, but flexion of the cervical spine produced some minor discomfort. Straight leg raising was full, but produced some pain in the lumbar spine. The tendon reflexes were present and equal. The plantar responses were flexor. Muscle power was normal and there were no other abnormalities.

The possibility of a non-paralytic poliomyelitis or a benign lymphocytic meningitis was considered and the patient was admitted to hospital for further investigations. The lumbar puncture produced a clear fluid under a pressure of $200 \mathrm{~mm}$. of water. Laboratorv investigations gave the following results:

Cells, 5 lymphocytes per c.mm., protein, $70 \mathrm{mg}$./ $100 \mathrm{ml}$., globulin, negative, chlorides, $620 \mathrm{mg}$. $100 \mathrm{ml}$, glucose, $62 \mathrm{mg} . / 100 \mathrm{ml}$.

The patient remained afebrile and her symptoms subsided within a few days.

She was eventually discharged to the Out-patient Department after 14 days in hospital. She was seen again four weeks later on September 24, 1956, when she stated that some days after returning home she again began to feel ill. On about September 10 there had been a recurrence of low backache and headache, and at the same time she noticed tender swellings in the right groin, followed a few days later by further swellings in the right axilla and in the neck.

Examination showed a widespread lymphadenopathy with discrete, tender glands palpable in the left posterior cervical chain, and a soft, tender gland in the left supraclavicular fossa some $\frac{3}{4} \mathrm{in}$. diameter, with similar glands in the right axilla and right groin.

The only other physical sign was a marked tenderness over the lumbar spine and the left sacro-iliac joint.

Within a few days the glands began to subside, but the patient continued to complain of severe pain over the lumbar spine and persistent headache.

Blood investigations were within normal limits, and lymphatic gland biopsy was carried out on October 17, glands being removed from the right axilla and the right inguinal region. The biopsy specimen revealed a histological picture compatible with so-called lympho-histiocytic medullary reticulosis (Robb-Smith, 1947), and it was decided to continue symptomatic treatment and to follow her progress as an outpatient. The lymphadenopathy continued to subside, and she was allowed home on November 3 with instructions to report for review in a further two weeks. 
During this interval it occurred to us that she might be a case of toxoplasmosis and when next seen on November 19 blood was taken for serum antibody tests. Strongly positive dye tests for toxoplasmosis were obtained together with a positive complementfixation test. Previous samples of sera were examined in retrospect for evidence of toxoplasmosis and a progressively rising titre diagnostic of acquired toxoplasmosis was found (Table I).

TABLE I

TOXOPLASMOSIS DYE AND COMPLEMENT-FIXATION TESTS

\begin{tabular}{|c|c|c|c|c|}
\hline & Date & & Dye Test & $\begin{array}{l}\text { Complement- } \\
\text { fixation Test }\end{array}$ \\
\hline $\begin{array}{l}17 / 8 / 56 \\
23 / 8 / 56 \\
19 / 11 / 56 \\
12 / 12 / 56\end{array}$ & $\begin{array}{ll}\ldots & \ldots \\
\cdots & \ldots \\
\ldots & \ldots \\
. & \end{array}$ & $\begin{array}{l}. . \\
\cdots \\
\cdots\end{array}$ & $\begin{array}{l}1 / 77 \\
1 / 102 \\
1 / 4,600 \\
1 / 12,000\end{array}$ & $\begin{array}{l}\text { Negative } \\
1 / 20 \\
1 / 20\end{array}$ \\
\hline
\end{tabular}

The patient continued to make steady progress and when last seen in January, 1957, was well and symptomless, and the lymphadenopathy had completely subsided.

\section{Pathology}

Two lymph glands were received for examination, one from the right inguinal region and one from the axilla. That from the inguinal region

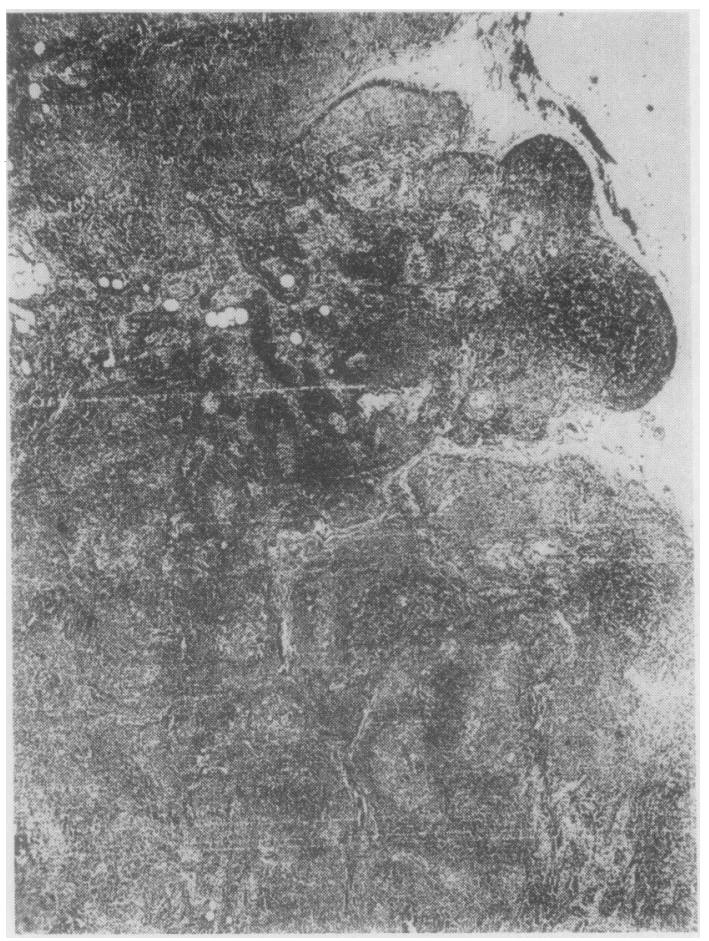

Fig. 1.-Exaggerated follicular pattern in an axillary gland. Haematoxylin and eosin, $\times 90$.

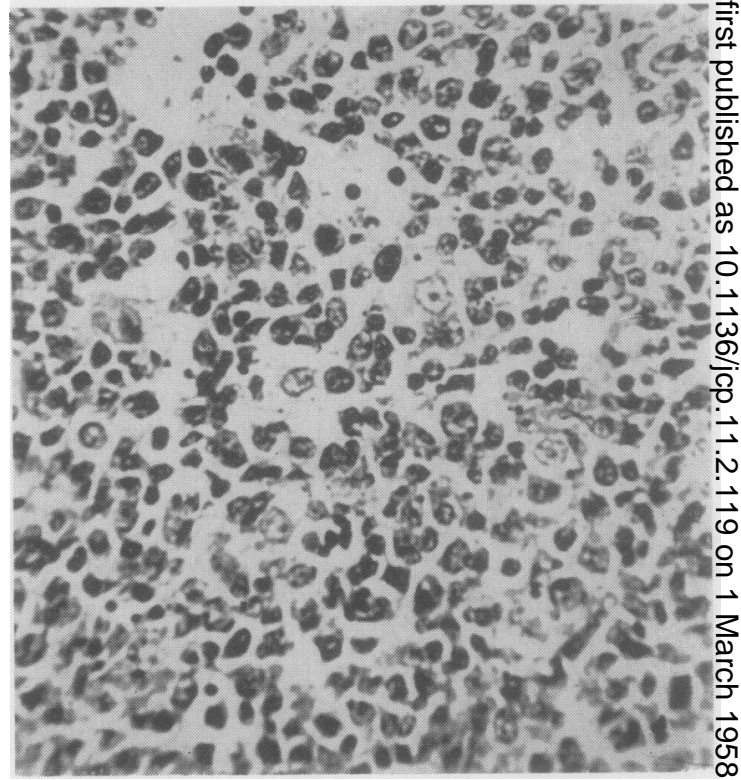

FIG. 2.-Scattered epithelioid cells in an axillary gland. Haematoxylin and eosin, $\times 380$.

measured $20 \mathrm{~mm}$. in diameter, and that from the axilla $9 \mathrm{~mm}$. diameter.

The histological appearances of both were $\stackrel{\mathbb{Q}}{\stackrel{\mathbb{Q}}{\varrho}}$ essentially similar. The follicular pattern was still $\overrightarrow{\overrightarrow{0}}$ present in the axillary gland (Fig. 1), but this was 3 less evident in that from the inguinal region.? Very striking were medullary collections of mono- and multinuclear epithelioid cells with an eosinophilic cytoplasm. There was no caseation? and no false follicle formation, but in some areas these collections of epithelioid cells showed $a_{i}$. sarcoid-like pattern (Fig. 2). Serial sections of $\frac{O}{3}$ the glands did not show any toxoplasma pseudocysts.

\section{Discussion}

In general the picture was similar to that described by Robb-Smith (1947) as lympho- histiocytic medullary reticulosis. It seems that ${ }_{0}$ this condition is a reactive one, although Robb- $-\frac{N}{\omega}$ Smith (1947) reported a survival rate of $95 \%$ aftero one year and $5.5 \%$ after 10 years.

The histological appearances in the lymph? glands in toxoplasmosis have been described by? other observers. Some of these changes are alsoo similar to those described as lympho-histiocytio medullary reticulosis.

Stanton and Pinkerton (1953) reported a diffuse $\stackrel{?}{?}$ reticulosis, on first impression suggestive of malignant lymphoid tumour. They noted that the follicular architecture was preserved, and stresse 
the presence of focal collections of eosinophilic histiocytes. In their case, by cutting serial sections of the glands, toxoplasma pseudocysts were found.

Skipper, Beverley, and Beattie (1954) described the appearance as being very similar to that seen in infectious mononucleosis. Small rounded groups of large cells were noted scattered through the gland pulp. Some of these were multinuclear.

Wahlgren (1951) reported the condition as subacute lymphadenitis with swelling of reticulum cells and agglomeration of eosinophilic leucocytes and plasma cells in the tissue. Other observers, however, have not stressed this medullary reaction in the lymph glands.

Siim (1952, 1953, 1954-5) and Gard and Magnusson (1951) discuss a mainly follicular lymphoid hyperplasia.

It appears that the changes in the lymph nodes in toxoplasmosis, whilst commonly reactive and non-specific in nature, can, when the disease is well established, be more characteristic. It is suggested, therefore, that toxoplasmosis be considered in any transient lymphadenopathy where the diagnosis remains obscure and especially where the histological appearances of the gland are of a non-specific or reactive character.
It would not appear possible, however, to make the diagnosis by histological examination alone, except in those cases where the parasites are actually demonstrable. Serological dye and complement-fixation tests are necessary.

\section{Summary}

A case of lymphadenopathy is described in which extreme reactive changes, resembling lympho-histiocytic medullary reticulosis, were found to be due to toxoplasmosis.

We wish to thank Dr. C. S. Darke for permission to publish this case, and we gratefully acknowledge the advice of Professor C. P. Beattie and the technical assistance of Mr. C. Lambourne.

Part of the work was aided by a grant from the Medical Research Council (J. K. A. B.).

\section{REFERENCES}

Gard, S., and Magnusson, J. H. (1951). Acta med. scand., $141,59$.

Pinkerton, H., and Henderson, R. G. (1941). J. Amer. med. Ass., $116,807$.

Robb-Smith, A. H. T. (1947). In Recent Advances in Clinical Pathology, ed. S. C. Dyke, p. 350. Churchill, London.

Sabin, A. B. (1941). J. Amer. med. Ass., 116, 801 .

Siim, J. C. (1951). Ibid., 147, 1641.

- (1952). Acta path. microbiol. scand., 30, 104.

(1953). Schweiz. Z. allg. Path., 16, 506.

(1954-5). Year Book of Pediatrics, p. 116

(1956). Ann. N.Y. Acad. Sci., 64, 185.

Skipper, Eric, Beverley, J. K. A., and Beattie, C. P. (1954). Lancet, 1, 287.

Stanton, M. F., and Pinkerton, H. (1953). Amer. J. clin. Path., 23, 1199.

Wahlgren, F. (1951). Nord. Med., 45, 349. 